\title{
Metasomatized peridotite xenoliths from the cretaceous rift-related Natash volcanics and their bearing on the nature of the lithospheric mantle beneath the southern part of the Eastern Desert of Egypt
}

\author{
NATSUE ABE ${ }^{1,2}$, ADEL A. SUROUR ${ }^{3}$, AHMED A. \\ MADANI $^{3}$ AND SHOJI ARAI ${ }^{1}$ \\ ${ }^{1}$ Kanazawa University \\ ${ }^{2}$ Institute for Marine-Earth Exploration and Engineer, JAMSTEC \\ ${ }^{3}$ Cairo University \\ Presenting Author: abenatsu@jamstec.go.jp
}

Highly carbonated mantle xenoliths have been found in riftrelated alkaline basalts at the Wadi Natash area in the southern part of the Eastern Desert of Egypt. Although all olivine and most orthopyroxene were replaced by carbonate and/or quartz, textural and mineral chemical features show that they are plagioclase-free spinel peridotites (lherzolite to harzburgite). The correlation between $\mathrm{Cr} \#$ ( 0.06 to 0.45$)$ and $\mathrm{Mg} \#$ ( 0.73 to 0.81 ) of the Cr-spinel in the studied xenoliths is weakly negative. Its $\mathrm{TiO} 2$ content is slightly higher than in abyssal peridotite that was not affected by melt injection. The clinopyroxene composition of high $\mathrm{Na} 2 \mathrm{O}$ contents $(>1.0 \mathrm{wt} \%)$ and $\mathrm{Al}^{\mathrm{VI}} / \mathrm{Al}^{\mathrm{IV}}$ ratios $(1.2-2.6)$ suggests its distinct signatures of a sub-continental mantle source. Two-pyroxene geothermometry indicates a temperature of about $900{ }^{\circ} \mathrm{C}$, which is slightly lower than that of ordinary spinel peridotite xenoliths from other rift zones. The studied peridotite xenoliths had experienced mantle processes (e.g., decompression melting, magma upwelling, and metasomatism) at a higher pressure than abyssal peridotites. The trace-element chemistry of clinopyroxene, e.g., high LREE/HREE ratios $\{(\mathrm{Ce} / \mathrm{Yb}) \mathrm{n}=7\}$, high LREE contents $(>3.6 \mathrm{ppm}$ and up to 30.0 $\mathrm{ppm} \mathrm{Ce}$ ) and high $\mathrm{Sr}$ between $>85.6 \mathrm{ppm}$ and $466 \mathrm{ppm}$ indicates metasomatic alteration of the peridotite. Clinopyroxene in one sample has very low $\mathrm{Ti} / \mathrm{Eu}$ and high LREE/HREE ratios. Clinopyroxene with $(\mathrm{Ce} / \mathrm{Yb}) n$ higher than $3-4$ and $\mathrm{Ti} / \mathrm{Eu}$ ratio lower than 1500 may have experienced carbonatite or carbonaterich melt metasomatism prior to their incorporation into the host basalt. The basalt itself is almost devoid of any carbonatization. Hence, the studied mantle peridotites were carbonatized before the generation of the basaltic magma but following an earlier event of K-metasomatism as indicated by the presence of phlogopite. The studied peridotites from the Wadi Natash area were altered by a carbonate-rich melt during a rifting stage. The results of the present paper indicate that the Natash basalts with their peridotite xenoliths extruded along with transversal fractures of the NW-trending Nuqra-Kom Ombo-Kharit continental rift on its western shoulder in the south Eastern Desert of Egypt. 